\section{Dr. W. E. Ripper}

Walter Eugen Ripper was born on January 24, 1906, in Austria, the son of Ministerialrat Max Ripper. He was a precocious child and a lot of his stimulus to scientific enquiry came from his father. He once told me that his earliest scientific publication was produced in his teens. He joined the United States Department of Agriculture as entomologist in 1931, working in Europe on the study of natural parasites for the control of pests introduced into the United States. He also acted as consultant to several large seed-growing estates in Austria and Hungary, devising special machinery for spraying unusual crops.

He realized that much good ontomological research was being frustrated by the fact that only growers of very expensive crops could afford the necessary spray equipment. In 1938, at a congress in Berlin, he met Sir Guy A. K. Marshall, director of the Commonwealth Institute of Entomology, who was worried by the same difficulty. As a result, Walter Ripper settled in Cambridge, and in 1939 founded Pest Control, Ltd., of which he was managing director and Sir Guy was chairman.

Their aim was to bridge the gap between research and farming by providing a complete service, including machines, chemicals, labour and technical advice. By training, experience and temperament, Ripper was probably better equipped than anyone in Europe for such an enterprise. A man of tremendous physical and mental energy, he worked from 8 a.m. to midnight, seven days a weok, driving himself sometimes to the verge of breakdown. A similar pace was expected of his staff, and it is a tribute to his power of inspiration that he was not disappointed.

For many people his drive to apply and exploit obscured an insatiable appetite for knowledge as such. Perhaps I saw more of this facet of a complox man than most. Except in the quiet tête-à-tête he would rarely admit ignorance, except, quite clearly, to himself, and then he would always take steps to correct it.

Ripper was always very quick to see the practical application of new research developments. In 1940 he introduced the weedkiller DNOC, which became mainly responsible for the disappearance of the picturesque sheets of red poppies which used to disfigure East Anglian cornfields. His first contract service in England was for the control of aphids by means of a portable nicotine fumigator. This gave a hitherto unobtainable degree of control, and without harm to predacious insects.

When the results of German research became available after the Second World War, Ripper was the first to seize on the idea of systemic insecticides, which could achieve soloctivity and access to hidden insects without the need for special machines. His first introduction, 'Schradan', was also selective, leaving predators to 'mop up' aphids which might survive to give rise to resistant strains. Ripper always thought in terms of 'tailor-made' insecticides, each designed to kill one pest selectively. However, the increasing strictness of regulations for the use of insocticides and the sheer cost of obtaining official approval for a product of relatively limited market forced him to abandon this ideal.

Bringing research results to the farm was very often an engineering problem, and Ripper devised many special machines for the purpose. Even before helicopters became available for civilian use he began to consider thoir use as air-borne spray machines, and was the first to develop commercial aerial crop-spraying in the United Kingdom.

Shortly after the tako-over of his Company by Fisons, Ltd., in 1953, Ripper severed contact with it. It was rather inevitable that the impatient initiator should not be in sympathy with the conservative policy the new management felt necessary to adopt. He joined the Dow Chemical Co., with whom he had had many previous contacts, to found their British subsidiary, Dow Agro- chemicals, Ltd., in King's Lynn, near to his second wife's large farm at Docking, on which he carried out many experiments. Ho left Dow to return to his interests in contract spraying, founding Crop Savia, Ltd., in the Sudan, and pursuing further the possibilities of 'robot' aircraft for crop spraying. At the time of his death he was giving much thought to the careful, technically supervised, use of insecticides to avoid undesirable sideeffects, a subject that had always been of intense interest to him.

He married first, in 1938, Berthe Siedeck, by whom he had a son and two daughters, and second, in 1952, Nancy Deacon. His son and his second wife intend to continue some at least of his uncompleted work.

\section{Dr. E. P. Jones}

Dr. Elwyn Parry Jones, or "P. J.", as he was invariably known to his friends and colleagues, was born in 1907 in Barry, Glamorgan, and educated at Taunton School. He obtained a first-class honours degree in zoology at the University of Wales and continued his education at the Imperial College of Tropical Agriculture, Trinidad, and at the University of Edinburgh, where he gained a Ph.D.

After a short period as a lecturer in the University of Aberdeen, he was seconded to the British South Africa Co. as a research entomologist at the Mazoe Citrus Experimental Station, Rhodesia, where he worked on the control of pests and diseases of citrus crops, until the beginning of the Second World War. After service in the Royal Air Force in Rhodesia, he was invited by Ripper to become the first managing director of a newly formed subsidiary company of Pest Control, Ltd., in Africa, and he was responsible for getting this Company, Pest Control (Contral Africa), Ltd., off the ground.

The major activity of this new Company was control of pests of the tobacco crop, but it was also eoncerned. with maintaining public health, and under Parry Jones's guidance it grew and thrived. Being closely associated with tobacco growing, he came to realize that there was an urgent need for a research centre to study improved pest control techniques if the industry was to survive and prosper, and he succeeded in interesting the Rhodesian. Government and the Rhodesia Tobacco Association in the formation of the Pest Control Research Scheme, in which his Company was a partner. This arrangement led to the setting up of the present Tobacco Research Board.

Although he was keenly interested in African affairs, he declined an invitation to onter Rhodesian politics, feeling he could serve the country and the pesticide industry better in the Company.

When he returned to the United Kingdom in 1953, he became a member of the board of the parent Company and, shortly afterwards, it was taken over by Fisons, Ltd., and became Fisons Pest Control, Ltd. In the same year, he was made technical general manager, and in this position he was responsible for the research work carried out at Chesterford Park Research Station, where important chemicals used in farming have been developed.

In 1958, Parry Jones was made joint managing director, and in 1961, chairman and managing director. He was also chairman of Fisons Farmwork, Ltd., a member of the Fisons group main board and of the board of Fisons: International Division.

Ho believed in long-term thinking, with an emphasis on a high level of research, and he considered the wellbeing of the staff to be of the greatest importance. He attached a high priority to education, and he took a great interest in the instructional courses organized by the Company for farmers, merchants, agricultural workers and advisers.

He saw the Company through its most difficult period. Wasteful marginal activities were pruned. Engineering research and development were abandoned, although the 